Julika Pasaribu, Mochammad Isa Anshori.

\title{
PENERAPAN WORK FROM HOME TERHADAP PRODUKTIVITAS KERJA (Studi Karyawan PT Berlian Jasa Terminal Indonesia)
}

\author{
Julika Pasaribu \\ Universitas Trunojoyo Madura \\ Mochammad Isa Anshori, S.E., M.Si \\ Universitas Trunojoyo Madura \\ 170211100202@student.trunojoyo.ac.id \\ isa.anshori@trunojoyo.ac.id
}

\begin{abstract}
The object of research was done on employees in Berlian Jasa Terminal Indonesia (BJTI) Port of Surabaya. Methodology this study used a quantitative method, the analysis of multiple regression. The sampling method by using sample random sampling with quantity of respondents as many as 65 respondents who are staff BJTI Port of Surabaya. The study to decide the relationship and impact of the implementation of work from home work productivity of employees BJTI Surabaya. The results of this study prove (1) time has positive and significant on work productivity with value $t_{\text {count }}$ is $13.780>t_{\text {table }} 1,67065$ and significant level has $0,000<0,05 ;(2)$ room (workspace) has positive and significant influence on work productivity with value $t_{\text {count }}$ is $3.215>t_{\text {table }} 1,67065$ and significant level has $0,002<0,05 ;(3)$ role of social has positive and significant influence on work productivity with value $t_{\text {count }}$ is $12.758>t_{\text {table }}$ is 1,67065 and significant level has $0,000<0,05 ;$ (4) Together or simultaneously that time, room and role of social has significant effect on work productivity, from the value of $\mathrm{F}_{\text {count }} 402.181>\mathrm{F}_{\text {tabel }} 2.76$ with significant level 0,000.
\end{abstract}

Keywords: Work from home, Time, Room, Role of Social, Work productivity and Covid-19.

\section{Pendahuluan}

Awal tahun 2020 beberapa Negara di dunia dihebohkan karena Pandemi global yakni Corona Virus Disease (COVID-19). Serangan virus ini berdampak besar pada kehidupan manusia di berbagai negara di dunia termasuk dari segi aspek Ekonomi, Kesehatan, Politik dan Keamanan. Hal ini telah menyebabkan perubahan metode kerja dan interaksi manusia dalam organisasi perubahan system kerja yaitu transformasi organisasi dalam memberikan pekerjaan terhadap karyawannya melalui tidak bekerja dari kantor tetapi bekerja dari rumah.

Dilansir dari "world health organization" atau Badan Kesehatan Dunia virus ini awalnya terjadi di Wuhan, Cina pada bulan Desember 2019. Virus ini dapat menyebar kepada orang lain melalui sempritan air liur, bersin, batuk hingga buang napas. Ketika sudah terkena virus covid-19 dianjurkan mengisolasi diri, berkomunikasi dengan keluarga atau masyarakat. Sehingga sangat berguna dakam menjaga jarak hingga lebih dari 1 meter dari orang yang terjangkit virus Corona. (http://kasusCovid19.tribunnews.com) diakses pada 20 September 2020.

Dengan adanya pandemi ini, secara tidak langung berpengaruh pula pada aktivitas Perusahaan, umumnya perusahan mengurangi produktivitasnya melalui keputusan Gubernur 


\section{Julika Pasaribu, Mochammad Isa Anshori.}

pada masing-masing daerah seperti adanya PSBB (Pembatasan Sosial Berskala Besar) sebagai upaya mencegah penularan virus ini. Di mana setiap orang tidak diperbolehkan untuk keluar rumah terkecuali ada kepentingan yang mendesak dan beberapa usaha yang tetap beroperasi pada masa PSBB yaitu warung atau toko yang menjual kebutuhan pokok dan kesehatan. Perusahaan memperkerjakan karyawan di rumah atau "Work from Home" yaitu perubahan dan pengalihan yang sebelumnya karyawan bekerja di kantor namun selama pandemic ini menjadi bekerja di rumah.

Research yang sudah diteliti oleh Richardson dkk, (2017) yaitu sisi positif bekerja dari rumah adalah para karyawan sesuai dengan kenyamanannya dalam memulai pekerjaannya. Peneliti juga menambah bahwa dampak negative seperti keterlambatan pekerjaan dan tidak ada penyerahan tugas atau pekerjaan pada waktu yang akan terjadi. Bagi banyak organisasi dapat menjadi keuntungan dengan kebijakan tersebut dimana banyak biaya yang dapat dipangkas seperti biaya listrik gedung, mess karyawan dan fasilitas penunjang kerja lainnya.

Pertimbangan seorang Manager dalam menjalankan wfh dengan tujuan tetap menjaga produktivitas staff, karyawan yang akses bertempat tinggal jauh dari kantor, melihat besarnya pengaruh produktivitas terhadap Perusahaan sangat penting dapat pencapaian sasaran dan tujuan perusahaan. sangat tepat dalam mengagapai produktivitas karena terdapat penghematan biaya dan waktu pada kendaraan karena jarak tempuh dari tempat tinggal ke kantor dengan jarak yang jauh sehingga sangat diuntungkan hasil penelitian menurut De Vos (2015).

Perusahaan yang dapat memelihara lingkungan kerja dapat membuat rasa nyaman pada karyawan dan karyawan tetap setia berada di perusahaan yang dapat memberikan lingkungan kerja yang positif karyawan juga merasa pekerjaannya berharga dan mendapat perhatian dan perusahaan harus fokus pada manajemen lingkungan kerja untuk memanfaatkan sumber daya manusia dengan lebih baik menuru Mohanti (2014).

Waktu dan tempat yang fleksibilitas menurut McCloskey (2018), namun memiliki kekurangan seperti tingkat produktivitas kerja kurang baik dan sistem pengawasan yang kurang maksimal oleh manajer. Sedangkan penelitian dari Lipper (2019) namun, selain memiliki kekurangan hasil studi juga menunjukkan bahwa memberikan fleksibilitas dan keleluasaan bagi karyawan untuk melakukan pekerjaannya tanpa diawasi oleh manajer atau atasannya.

penyebab lain menurunnya produktivitas kerja selama pandemi yaitu kurangnya pengawasan terhadap karyawan sehingga menyebabkan hilang motivasi kerja, fokus hilang karena banyaknya penghalang atau penganggu yang membuat para karyawan kehilangan fokus atau konsentrasi terhadap tugasnya sering terjadi miskomunikasi dan masalah keamanan data. Narpati dalam Larson et al. (2020: 12).

Work from home adalah strategi yang dianut oleh banyak organisasi dengan bekerja dari rumah upaya untuk meningkatkan produktivitas pada masa pandemi setiap perusahaan mempunyai kebijakan sendiri dengan menerapkan seminggu sekali dan terdapat dua tim bekerja secara bergiliran bekerja di rumah dan kantor teruntuk staff yang kurang fit dan sakit dipersilahakan untuk bekerja di rumah ataupun beberapa hari karena keperluan penyemprotan disinfektan. Bekerja dari rumah pasti memiliki pekerjaan atau kewajiban tetapi pelaksanaannya terdapat kendala, kekurangan bahkan tantangan karena ada beberapa pekerjaan yang tidak semua bisa dilakukan di rumah. Banyak kendala terdapat pada "work from home" contoh gangguan lingkungan keluarga, koordinasi, komunikasi sesama karyawan, alat-alat kantor dan lain sebagainya.

Dari pemaparan diatas peneliti tertarik melakukan penelitian dengan topic penerapan work from home terhadap produktivitas kerja karyawan studi karyawan BJTI Surabaya dengan alasan masih terdapat kendala yang terjadi seperti tugas yang dikerjakan tidak maksimal, masih ada karyawan yang tidak memiliki ruangan khusus untuk bekerja dan jaringan internet yang 
tidak stabil serta kualitas kerja dan efisiensi yang sulit dikontrol. Berdasarkan hal tersebut peneliti menganggkat judul dari permasalahan tersebut.

\section{Tinjauan Pustaka}

\section{Sejarah Work From Home}

Kurland dan Bailyn (2010) menguraikan bahwa terjadi perubahan cara kerja dari beberapa tahun lalu yang kaitannya dengan tempat bekerja staff. Karyawan telah menemukan tempat kerja supaya mendapatkan kesempatan untuk melakukan tugas atau pekerjaan sehari-hari setiap saat, pada lokasi yang sudah dipilih. Selain itu Ellis (2016) menyatakan bahwa jumlah karyawan yang melakukan work from home di Inggris telah meningkat selama 10 tahun terakhir dari jumlah keseluruhan karyawan menjadi 1,5 juta. Bahwa lebih banyak pekerja laki-laki daripada perempuan yang melakukan work from home, namun peningkatan nyata selama beberapa tahun terakhir menurut Trades Union Congress (2013).

Menurut Morganson $d k k$, (2014) mengatakan bahwa difokuskan pada pengkategorian karyawan dalam hal kepuasan kerja dan work life balance . fokus pada pekerja yang bekerja di kantor dan dirumah. Studi ini menyimpulkan bahwa penelitian perlu dilakukan untuk focus pada kegiatan dan kebijakan kerja. Cara ini menuai ada setuju dan tidak yang dipublikasikan tahun 1976 oleh Jack Nilles dengan rekannya oleh Carlson. Laporan tersebut menyatakan pada manfaat dan biaya transportasi dari rumah ke kantor.

\section{Definisi Work From Home}

Work from home disebut seseorang yang telecommute atau dikenal sebagai "telecommuter", "teleworker", dan sebagai karyawan sumber dari rumah atau pekerja di rumah sumber dari Wikipedia n.d. wfh isitilah saat ini banyak digunakan selama masa pandemic karena sebagian karyawan melakukan tugas dan pekerjaan dari rumah. Singkatan yang sering digunakan dalam komunikasi digital untuk memberitahu seseorang bekerja dari rumah pada hari aktif kerja melakukan pekerjaan seseorang di rumah dan bukan di gedung seperti Kantor menurut Merriam dalam Narpati (2020: 12).

Bekerja dari rumah adalah kebijakan dimana seorang pekerja memenuhi tanggung jawab dan tugasnya sambil tetap dirumah, dengan menggunakan Teknologi Informasi dan Komunikasi (TIK). Istilah "work from home" digunakan merujuk pada teleworking sebagai alternative kebijakan sementara. Atau suatu istilah bagi para pekerja dengan bekerja dari jarak jauh. pekerjaan yang dilakukan di rumah dengan minimal waktu bekerja selama 20 jam per minggu menurut Crosbie \& Moore (2014).

\section{Manfaat Work From Home}

Penghematan bagi perusahaan, sebagaimana dijelaskan oleh Radcliffe (2015: 2) yaitu infrastruktur, listrik, air dan AC termasuk biaya telepon dan internet, petugas kebersihan dan keamanan. Melangkah ke ramah lingkungan juga membantu system tersebut, karena kebanyak pekerja menggunakan transportasi seperti mobil ke kantor sehingga dapat meningkatkan penggunaan bahan bakar. Graaf dan Rietveld (2007: 157) mengatakan bahwa perusahaan dapat menghemat pada pemberian gaji ketika work from home, karena gaji karyawan rata-rata $19 \%$ lebih rendah dari gaji karyawan yang bekerja dari kantor.

Menurut Wen, Kite dan Rissel (2010: 2) ketika bepergian untuk bekerja tidak hanya berkontribusi pada kemacetan lalu lintas, polusi udara, dan tingkat aktivitas fisik lebih rendah, tetapi juga secara signifikan terkait dengan kelebihan berat badan dan obesitas populasi umum. untuk menyimpulkan terkait Fu $d k k$, (2012: 421) pola penggunaan lahan dan infrastruktur 


\section{Julika Pasaribu, Mochammad Isa Anshori.}

transportasi umum terbukti memiliki pengaruh terhadap pekerja dari rumah. Jarak dan akses internet secara signifikan meningkat terhadap pekerja yang berada di rumah, menunjukkan bahwa jarak perjalanan yang jauh membuat seorang pekerja untuk bekerja dari rumah dengan konektivitas TIK yang dapat memberikan platform untuk realisasi teleworking.

\section{Dimensi WFH}

Menurut Gadecki et al. (2018: 250) ada tiga dimensi penerapan atau terwujudnya work from home yaitu sebagai berikut :

a. Ruang (Room): Transformasi ruang pribadi rumah (sebagai tempat kesukaan dan mengekspresikan diri)

b. Waktu (Time): Penggunaan ruang pribadi sebagai ruang kerja yang membuat efektif dan efisien.

c. Peran Sosial: Narasi tentang diri sendiri sebagai pekerja dari rumah, sebuah emansi peran dan posisi teleworker yang konstan dilakukan.

\section{Indikator WFH}

Menurut Timbal dan Mustabsat (2016) dalam Farrell Kathleen (2017) berikut indikator dari wfh yakni:
a. Tempat kerja fleksibel
b. Tekanan atau stres
c. Keharmonisan terhadap keluarga
d. Kesehatan dan work life balance
e. Kreativitas

\section{Pengertian Produktivitas Kerja}

Menurut Hasibuan dalam Ernawati (2016: 38) menyatakan bahwa sebenarnya produktivitas mengandung tekad bahwa hasil kerja karyawan bisa memenuhi target dan sasaran. Secara umum, produktivitas kerja disebut juga dengan bahwa hasil output dan input yang dihasilkan. Di dunia kerja, ada berbagai konsep dan didefinisikan mengenai produktivitas. Produktivitas tenaga kerja membantu dalam meningkatkan pertumbuhan ekonomi di suatu Negara. Produktivitas tenaga kerja mengacu pada kuantitas barang dan jasa yang dihasilkan oleh karyawan dalam jam. Termasuk keselamatan kerja, kesehatan, dan kesejahteraan kerja memiliki dampak yang luar biasa terhadap produktivitas karyawan. Tenaga kerja dapat berjalan dari komunitas kerja yang sejahtera. Berbagai penelitian membuktikan bahwa pekerja yang sehat dan puas dapat membantu meningkatkan produktivitas suatu perusahaan. Mengembangkan masala kesejahteraan dalam organisasi mana pun pasti akan memberikan dampak positif pada produktivitas perusahaan (Handoko, 2016: 46).

Menurut Swastha (2014: 281) produktivitas merupakan konsep yang mendeskripsikan bahwa hasil untuk menggapai sesuatu. Sedangkan menurut (Rusli Syarif, 2014:1) adalah rumusan dari produktivitas total dari ratio dari produksi hasil terhadap apa yang dipergunakan untuk mendapatkan hasil tersebut. Produktivitas mencakup daya dan hasil guna. Dengan menggambarkan pada tingkat SDM, dana, dan alam untuk mendapatkan hasil dan menggambarkan akibat dan kualitas dari hasil tersebut.

\section{Indikator Produktivitas Kerja}

Menurut Dharma (2013) yaitu indikator produktivitas kerja, meliputi: 
a. Quality Pekerjaan

Kualitas berkaitan pada peningkatan hasil kerja jika bagus akan dapat meningkatkan pada mutu yang dihasilkan. Karyawan penunjang SDM yang bisa mengatur suatu organisasi yang sesuai harapan perusahaan.

b. Kuantitas Pekerjaan

Kuantitas menyakut hasil dan target yang dicapai sesuai plan suatu organisasi, Perbandingan quantitas staff mampu seimbang dengan kualitas pekerjaannya sehingga dikatakan pekerja produktif sesuai hasil kerjanya.

c. Ketetapan waktu

Beberapa budaya lain mengambil suatu pendekatan lain terhadap waktu. Mereka memfokuskan pada masa lalu seperti mengikuti tradisi dan berusaha melestarikan prakteknya .Sumber daya harus mampu digunakan dengan benar danmelaksanakan setiap tanggung jawabnya.

d. Semangat Kerja

Semangat kerja sangat berdampak pada kegiatan karyawan apabila suatu organisasi bekerja dengan semangat, senang, ramah dengan sesama karyawan maka dapat menjadi penunjang produktivitas tinggi.

e. Disiplin kerja

Tenaga kerja jika mempunyai disiplin kerja akan berdampak besar bagi karyawan dan perusahaan sehingga tugas, jadwal kerja, kebijakan perusahan dapat dipatuhi sesuai harapan setiap perusahaan. Peneliti menggunakan indikator produktivitas kerja yang dinyatakan oleh Agus Dharma (2013) sebagai variabel dependent yang berhubungan dengan produktivitas.

\section{Manfaat Produktivitas Kerja}

Manfaat produktivitas menurut David Summanth dalam Friyatiningsih (2012:42) adalah sebagai berikut :

1. Instansi mengevaluasi efisiensi dari SDM yang digunakan dalam menghasilkan barang atau jasa.

2. Pengukuran produktivitas yang bertujuan pada system planning resource dalam waktu jangka panjang dan pendek.

3. Hasil digunakan untuk mentargetkan tingkat efisiensi dimasa yang akan datang.

\section{Upaya Peningkatan Produktivitas}

Pekerja atau masyarakat yang dilandasi pada norma dan nilai yang bersifat mengikat serta etos kerja yang dipegang teguh karyawan. Yang dimana setiap pekerja dapat meningkatkan inisiatif dan dapat diandalkan sebagai keberlangsungan anggota pada suatu organisasi. Produktivitas yang meningkat perlu adanya upaya. Adapun upaya dalam meningkatkan produktivitas menurut Siagian dalam Sutrisno (2011) yaitu :

1. Pemberdayaan SDM

Human resource development bepengaruh dalam struktur organisasi sehingga, memberdayakan SDM merupakan etos kerja yang dimana setiap pekerja dapat meningkatkan inisiatif dan dapat diandalkan pada tingkatan organisasi. Memberdayakan SDM berlandaskan pada nilai dan implementasi manajemen dengan demokrasi pada organisasi.

2. Peningkatan kualitas hasil pekerjaan

Kualitas idak hanya berdasarkan produk yang dihasilkan baik berupa jasa dan barang tetapi, berkaitan dan menyangkut semuanya berkaitan dalam organisasi yang terlibat. Kualitas menyangkut jenis kegiatan baik tugas pokok ataupun tugas penunjang dalam organisasi. Jika 
perusahaan mendapatkan penghargaan dalam bentuk ISO 9000 sehingga bukan hanya dinilai dari mutu produk yang dihasilkan tetapi, berdasarkan semua jenis pekerjaan dan proses manajerial yang ada pada organisasi.

3. Evaluasi dan perbaikan secara terus-menerus

Dalam hal ini sangat diperlukan melakukan perbaikan terus-menerus untuk meningkatkan produktivitas. Yang dapat dievaluasi secara internal dan eksternal. Secara internal dapat mengevaluasi dari strategi perusahaan, perubahan kebijakan perusahan, dan berbagai

\section{Kerangka Penelitian}

Menurut Sugiyono (2016: 60) menyatakan bahwa kerangka konseptual tentang gambaran theory berhubngan dengan variabel yang tetapkan dengan sumber teori yang dideskripsikan. Dengan sumber referensi yang mendukung penelitian, maka dapat digambarkan kerangkan pemikiran penerapan wfh terhadap Produktivitas kerja karyawan pada BJTI Port Surabaya.

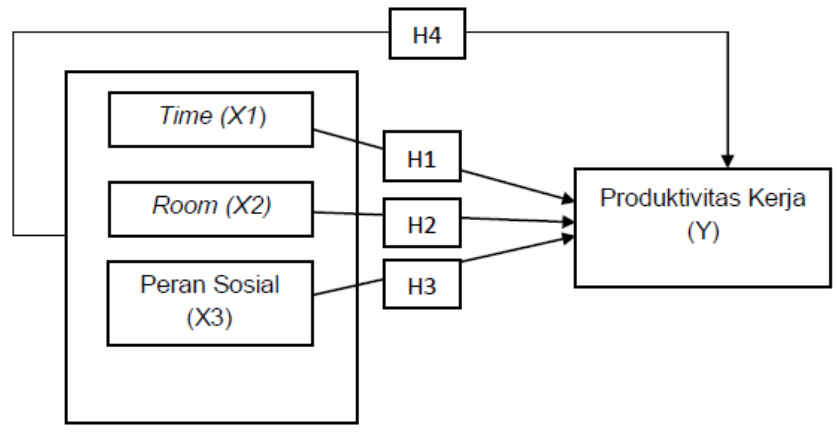

Gambar 1 Kerangka Berpikir.

Sumber: Maria Helena (2020:25) dan Putri Dwi (2016:35).

\section{Metode Penelitian}

Jenis penelitian ini yaitu kuantitatif dan pengolahan data dibantu oleh software SPSS 21.

\section{Lokasi Penelitian}

Lokasi atau objek Penelitian yang dilakukan di PT. BJTI (Berlian Jasa Terminal) Port Surabaya terletak di jalan Perak Barat No. 379, Perak Utara, Kecamatan Pabean Cantian, Kota Surabaya, Jawa Timur 60165.

\section{Jenis Penelitian}

Jenis penelitian yang dilakukan dari studi kasus penelitian ini yaitu tipe penelitian kuantitatif deskriptif dengan tujuan mendapatkan hasil variabel dengan lain ada penghubung dengan variabel lain atau membuat perbandingan. Adapun pengertian deskriptif menurut Sugiyono (2016: 29) yaitu metode yang mengambarkan pada lokasi penelitian berdasarkan data atau sampel diambil untuk mendapatkan supaya dapat melakukan penarikan kesimpulan pengambilan data.

\section{Data dan Sumber Data}

Data yang dianalisis pada penelitian ini dengan quantative menurut Sugiyono (2016: 7) method kuantitatif sering disebut metode positivistik Karena atas dasar positivism yang diteliti 
dari populasi dan sampel, analisis data tersebut mengetahui hipotesis yang telah ditentukan. Sedangkan sumber data denga primer dan sekunder.

a. Data primer

Menurut Sugiyono (2016:225) data didapatkan peneliti secara langsung melalui sumber datanya karena data primer diperoleh secara langsung. Data primer ialah data yang diperoleh langsung dari lapangan atau lokasi penelitian. Pegumpulan data ini biasanya dengan observasi dilapangan, hasil wawancara dan kuisioner responden.

b. Data Sekunder

Menurut Sugiyono(2016:225) mengemukakan bahwa data sekunder yaitu data tidak diperoleh langsung kepada objek peneltian atau sumber yang dikumpulkan secara tidak lansung dari datanya. Data sekunder dari penelitian ini yaitu gambaran umum, bentuk organisasi perusahaan mengenai objek penelitian di BJTI Port Surabaya serta data pendukung berupa studi pustaka, jurnal yang berhubungan dengan permasalahan peneliti, dan dokumen laporan yang berkaitan dengan penelitian ini.

\section{Teknik Pengumpulan Data}

Proses pengumpulan data dilakukan peneliti untuk mengumpulkan datanya dengan langkah yang terpenting untuk mengetahui dan mendapatkan datanya Sugiyono (2016: 224). cara memperoleh data dari informasi dalam peneltian ini adalah wawancara, kuesioner, dan dokumen.

\section{Teknik Analisis Data}

Teknik analisis pada penelitian ini yaitu: (1) Uji Validitas dan Reliabilitas mengetahui valida tau tidaknya instrumen dari indek korelasi product moment Pearson dengan significance level 5\%. Uji reabilitas dengan pendekatan Alpha Cronbach lebih besar dari 0,06 maka dapat diandalkan atau sebaliknya. (2) Uji asumsi klasik jika memenuhi syarat dari (uji normalitas, multikolineritas dan heteroskedastisitas) maka dapat dikatakan model regresi yang baik. (3) Uji Hipotesis untuk menguji pengaruh variabel bebas secara simultan (Uji F), parsial (Uji T) dan koefisien Determinasi $\left(\mathrm{R}^{2}\right)$.

\section{Hasil dan Pembahasan}

Penerapan work from home terhadap produktivitas kerja di masa pandemi covid-19 di PT. Berlian Jasa Terminal Indonesia (BJTI) Surabaya. Penelitian dilakukan dengan menyebar kuesioner secara online kepada staff yang ada diperusahaan sebanya 65 responden. Didapati hasil analisis deskriptif karakteristik responden yaitu dari kategori usia 21-30 sebanyak 14 responden, 31-40 sebanyak 32 responden, 41-50 sebanyak 14 responden, 51-60 sebanyak 5 responde. Pekerja perempuan sebanyak 12 orang dan laki-laki sebanyak 53 responden, kategori pendidikan tingkat SMA 14 orang, D3 ada 7 orang, S1 ada 41 orang, S2 ada 3 orang, dan kriteria status menikah sebanyak 59 orang dan belum menikah 6 orang.

\section{Uji Validitas dan Reabilitas}

Tabel 1. Hasil uji validitas time (X1)

\begin{tabular}{|l|l|l|l|}
\hline Item Pernyataan & $\mathbf{R}_{\text {hitung }}$ & $\mathbf{R}_{\text {tabel }}$ & Keterangan \\
\hline $\mathrm{X}_{\cdot 1.1 \cdot 1}$ & 0,556 & 0,2441 & Valid \\
\hline $\mathrm{X}_{\cdot 1.1 .2}$ & 0,751 & 0,2441 & Valid \\
\hline $\mathrm{X}_{.1 .2 .1}$ & 0,686 & 0,2441 & Valid \\
\hline
\end{tabular}


Julika Pasaribu, Mochammad Isa Anshori.

\begin{tabular}{|l|l|l|l|}
\hline X.1.2.2 & 0,483 & 0,2441 & Valid \\
\hline X.1.3.1 & 0,451 & 0,2441 & Valid \\
\hline X.1.3.2 & 0,575 & 0,2441 & Valid \\
\hline
\end{tabular}

Sumber : Data diolah 2021

Tabel 2. Hasil uji validitas room (X2)

\begin{tabular}{|l|c|c|l|}
\hline Item Pernyataan & $\mathbf{R}_{\text {hitung }}$ & $\mathbf{R}_{\text {tabel }}$ & \multicolumn{1}{|c|}{ Keterangan } \\
\hline $\mathrm{X} \cdot 2.1 \cdot 1$ & 0,638 & 0,2441 & Valid \\
\hline $\mathrm{X} \cdot 2.1 .2$ & 0,645 & 0,2441 & Valid \\
\hline $\mathrm{X} \cdot 2.2 .1$ & 0,545 & 0,2441 & Valid \\
\hline $\mathrm{X} \cdot 2.2 .2$ & 0,553 & 0,2441 & Valid \\
\hline $\mathrm{X} \cdot 2.3 .1$ & 0,540 & 0,2441 & Valid \\
\hline $\mathrm{X} \cdot 2.3 .2$ & 0,518 & 0,2441 & Valid \\
\hline
\end{tabular}

Sumber : Data diolah 2021

Tabel 3. Hasil uji validitas peran sosial (X3)

\begin{tabular}{|l|c|c|l|}
\hline Item Pernyataan & $\mathbf{R}_{\text {hitung }}$ & $\mathbf{R}_{\text {tabel }}$ & \multicolumn{1}{|c|}{ Keterangan } \\
\hline X.3.1.1 & 0,294 & 0,2441 & Valid \\
\hline X.3.1.2 & 0,733 & 0,2441 & Valid \\
\hline X.3.2.1 & 0,735 & 0,2441 & Valid \\
\hline X.3.2.2 & 0,368 & 0,2441 & Valid \\
\hline X.3.3.1 & 0,599 & 0,2441 & Valid \\
\hline X.3.3.2 & 0,579 & 0,2441 & Valid \\
\hline
\end{tabular}

Sumber : Data diolah 2021

Tabel 4. Hasil uji validitas variabel produktivitas (Y)

\begin{tabular}{|l|c|c|l|}
\hline Item Pernyataan & $\mathbf{R}_{\text {hitung }}$ & $\mathbf{R}_{\text {tabel }}$ & \multicolumn{1}{|c|}{ Keterangan } \\
\hline$Y_{2.1 .1}$ & 0,596 & 0,2441 & Valid \\
\hline$Y_{2.1 .2}$ & 0,677 & 0,2441 & Valid \\
\hline$Y_{2.2 .1}$ & 0,423 & 0,2441 & Valid \\
\hline$Y_{2.2 .2}$ & 0,407 & 0,2441 & Valid \\
\hline$Y_{2.3 .1}$ & 0,388 & 0,2441 & Valid \\
\hline$Y_{2.3 .2}$ & 0,681 & 0,2441 & Valid \\
\hline$Y_{2.4 .1}$ & 0,609 & 0,2441 & Valid \\
\hline$Y_{2.4 .2}$ & 0,376 & 0,2441 & Valid \\
\hline$Y_{2.5 .1}$ & 0,529 & 0,2441 & Valid \\
\hline$Y_{2.5 .2}$ & 0,569 & 0,2441 & Valid \\
\hline$Y_{2.6 .1}$ & 0,620 & 0,2441 & Valid \\
\hline$Y_{2.6 .2}$ & 0,416 & 0,2441 & Valid \\
\hline
\end{tabular}

Sumber : Data diolah 2021

Hasil uji validitas menujukkan bahwa terlihat dari data tersebut seluruh instrument penelitian valid dan hasil korelasi $<5 \%(0,05)$. 
Julika Pasaribu, Mochammad Isa Anshori.

Tabel 5. Hasil Perhitungan Uji Reliabilitas

\begin{tabular}{|l|c|l|l|}
\hline Variabel & Croncbach's alpha & Kriteria & Keterangan \\
\hline Time & 0,616 & 0,60 & Reliabel \\
\hline Room & 0,678 & 0,60 & Reliabel \\
\hline Peran sosial & 0,644 & 0,60 & Reliabel \\
\hline Produktivitas Kerja & 0,749 & 0,60 & Reliabel \\
\hline
\end{tabular}

Sumber : Data diolah 2021

Hasil uji reabilitas menujukkan bahwa seluruh instrument reliable karena memiliki nialai Cronbach alpha diatas 0.6.

\section{Uji asumsi klasik}

\section{Uji Normalitas}

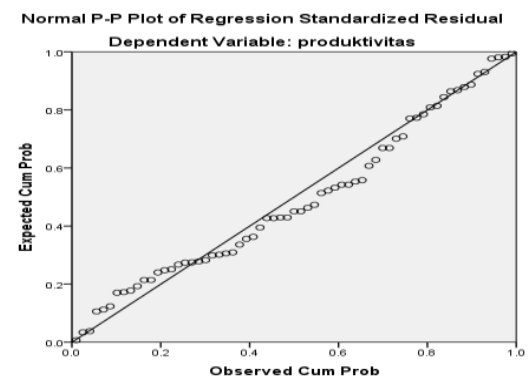

Gambar 2. Uji Normalitas dengan Normal P-P Plot

(referensi : data diolah dengan SPSS V21, 2021)

Pengujian hasil dari gambar 4.1 disimpulkan ternyata penyebaran titik garis diagonal tidak menyebar jauh dari garis diagonal dan mengikut garis diagonal sehingga dapat dikatakan terpenuhi syarat dari asumsi normalitas.

Tabel 6. Hasil Uji Kolmogorof-Smirnov

\section{One-sample Kolmogorov-Smirnov Test}

\begin{tabular}{|c|c|c|}
\hline & & $\begin{array}{c}\text { Unstandardized } \\
\text { Residual }\end{array}$ \\
\hline $\mathrm{N}$ & & \\
\hline Normal & Mean &, 0000000 \\
\hline Parameters ${ }^{a, b}$ & $\begin{array}{l}\text { Std. } \\
\text { Deviation }\end{array}$ & 1,04742603 \\
\hline Most Extreme & Absolute & 102 \\
\hline Differences & Positive & 102 \\
\hline & Negative &,- 072 \\
\hline Kolmogorov-S & & 821 \\
\hline Asymp. Sig. (2 & & 511 \\
\hline
\end{tabular}

a. Test distribution is normal

b. Calculated from data.

Dari hasil uji diatas menggunakan one sample Kolmogrov-smirnov dengan nilai sig lebih besar dari 0,05 atau 5\% maka dikatakan model tersebut memenuhi syarat normalitas. 


\section{Uji Heteroskedastisitas}

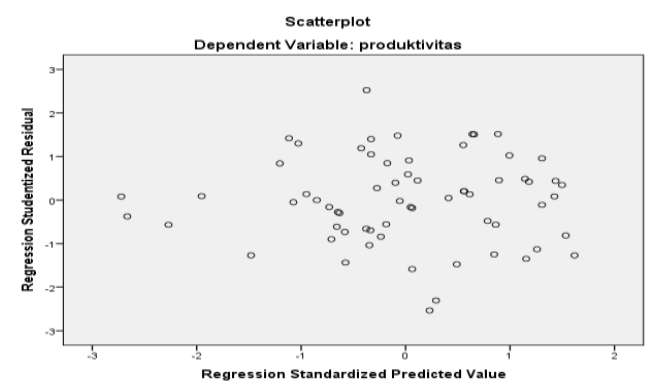

Gambar 3. Uji Heteroskedastisitas (referensi: Data diolah, 2021)

Dari hasil uji diatas hasil scatterplot tidak membentuk suatu pola dan titik menyebar diatas atau dibawah angka 0 pada sumbu Y.

\section{Uji Multikolineritas}

Tabel 7. Hasil Uji Multikolineritas

\begin{tabular}{|l|l|l|l|}
\hline \multirow{3}{*}{$\begin{array}{l}\text { Persamaan } \\
\text { Regresi }\end{array}$} & \multicolumn{1}{|c|}{ Variabel } & Tolerance & \multicolumn{1}{c|}{ VIF } \\
\cline { 2 - 4 } & Time $\left(\mathrm{X}_{1}\right)$ & 0,537 & 1.863 \\
\cline { 2 - 4 } & Room $\left(\mathrm{X}_{2}\right)$ & 0,597 & 1.675 \\
\cline { 2 - 4 } & Peran sosial $\left(\mathrm{X}_{3}\right)$ & 0,576 & 1.736 \\
\hline
\end{tabular}

Sumber : Data diolah 2021

Dari hasil uji diatas tidak ada nilai tolerance kurang dari 0,1 dan VIF lebih dari 10 sehingga tidak terjadi multikolineritas antara variabel satu dengan variabel lainnya.

\section{Uji hipotesis dan análisis regresi berganda}

\section{Uji F}

Tabel 8. Hasil Perhitungan Uji F (Simultan)

\begin{tabular}{|c|c|c|c|c|c|c|}
\hline \multicolumn{7}{|c|}{ ANOVA $^{a}$} \\
\hline & & $\begin{array}{l}\text { Sum of } \\
\text { Squares }\end{array}$ & Df & Mean Square & $\mathrm{F}$ & Sig. \\
\hline \multirow{3}{*}{1} & Regression & 1388.801 & 3 & 462.934 & 402.181 & $.000^{\mathrm{b}}$ \\
\hline & Residual & 70.214 & 61 & 1.151 & & \\
\hline & Total & 1459.015 & 64 & & & \\
\hline
\end{tabular}

b. Predictors: (Constant) , TX3, TX2, TX1

Hasil dapat diperoleh dari nilai $F_{\text {hitung }}$ dari uji $F$ sebesar $402.181>F_{\text {tabel }} 2.76$ dengan sig 0,000. Hasil membuktikan bahwa terdapat pengaruh positif dan signifikan secara simultan dari Time (X1), Room (X2), Peran Sosial (X3) terhadap Produktivitas kerja (Y). 
Julika Pasaribu, Mochammad Isa Anshori.

\section{Uji T}

Tabel 9. Hasil Uji t (Parsial)

Coefficients $^{\mathbf{a}}$

\begin{tabular}{|c|c|c|c|c|c|c|}
\hline \multirow{2}{*}{\multicolumn{2}{|c|}{ Model }} & \multicolumn{2}{|c|}{$\begin{array}{l}\text { Unstandardized } \\
\text { Coefficients }\end{array}$} & \multirow{2}{*}{$\begin{array}{c}\begin{array}{c}\text { Standardize } \\
\mathrm{d} \\
\text { Coefficients }\end{array} \\
\text { Beta }\end{array}$} & \multirow[t]{2}{*}{$\mathrm{T}$} & \multirow[t]{2}{*}{ Sig. } \\
\hline & & B & Std. Error & & & \\
\hline \multirow{4}{*}{1} & (Constant) & .356 & 1.470 & & .242 & .810 \\
\hline & TX1 & .865 & .063 & .528 & 13.780 & . 000 \\
\hline & TX2 & .206 & .064 & .117 & 3.215 & .002 \\
\hline & TX3 & .923 & .072 & .472 & 12.758 & .000 \\
\hline
\end{tabular}

a. Dependent Variable: TY

Berdasarkan tabel diatas bahwa Time (X1), Room (X2), Peran Sosial (X3) berpengaruh positif dan signifikan terhadap Produktivitas kerja (Y) dengan $t_{\text {hitung }}>t_{\text {tabel }}$ sebesar lebih besar dari tabel yaitu sebesar 1,67065 dengan taraf signifikan 0,05 sehingga hasil membuktikan sebagai berikut:

1. Variabel Time (X1)

Nilai thitung variabel time sebesar 13,780 dengan tingkat signifikan $0.000<0,05$. Hasil ini membuktikan bahwa Time memiliki pengaruh positif dan signifikan pada produktivitas kerja.

2. Variabel Room (X2)

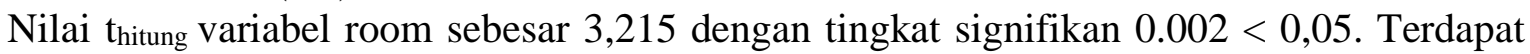
hasil yang membuktikan bahwa room berpengaruh positif dan signifikan terhadap produktivitas kerja.

3. Variabel Peran Sosial (X3)

Nilai thitung variabel peran sosial sebesar 12,758 dengan tingkat signifikan $0.000<0,05$. Hasil ini membuktikan bahwa peran sosial berpengaruh positif dan signifikan terhadap produktivitas kerja.

\section{Uji Koefisien Determinasi}

Tabel 10. Hasil Perhitungan Uji Koefisien Determinasi

\begin{tabular}{|l|r|r|r|c|}
\hline Model & R & R Square & $\begin{array}{c}\text { Adjusted R } \\
\text { Square }\end{array}$ & $\begin{array}{c}\text { Std. Error of the } \\
\text { Estimate }\end{array}$ \\
\hline 1 & $.976^{\mathrm{a}}$ & .952 & .950 & 1.073 \\
\hline
\end{tabular}
a. Predictors: (Constant), TX3, TX2, TX1
b. Dependent Variable: TY

Berdasarkan tabel diatas diperoleh hasil regresi $\mathrm{R}=0,976$ atau $97,6 \%$ terlihat terdapat hubungan yang positif dan signifikan antara variabel time, room, peran sosial terhadap produktivitas kerja karyawan Berlian Jasa Terminal Indonesia, sisanya 2,4\% dipengaruhi oleh faktor-faktor lain yang tidak diteliti dalam penelitian ini. Kemudian, diketahui bahwa Adjusted R square diperoleh sebesar 0,950 artinya 95\% produktivitas karyawan Berlian Jasa Terminal Indonesai dipengaruhi atau bisa dijelaskan oleh variabel bebas dari time, room dan peran sosial dengan sisanya $5 \%$ dipengaruhi oleh variabel lain yang tidak diteliti dalam penelitian ini. 
Julika Pasaribu, Mochammad Isa Anshori.

\section{Kesimpulan}

Berdasarkan hasil pembahasan di atas dapat disimpulkan sebagai berikut:

1. Variabel time secara berpengaruh positif dan signifkan sebesar 6.841 terhadap produktivitas kerja dengan nilai signifikan sebesar $0,000<0,05$. Artinya semakin karyawan dalam mengelola waktu dengan baik maka semakin tinggi produktivitas yang dihasilkan oleh PT. Berlian Jasa Terminal Indonesia dengan tidak menunda pengerjaan tugas.

2. Variabel room terdapat pengaruh positif dan signifikan sebesar 3.376 terhadap produktivitas kerja dengan nilai signifikan 0,001 $<0,05$. Artinya semakin nyaman dan rapi tempat kerja maka semakin banyak inovasi dan kreatif yang diciptakan serta dapat konsentrasi dengan baik dengan selalu menjaga kenyamanan dan kebersihan ruangan kerja.

3. Variabel peran sosial berpengaruh positif dan signifikan sebesar 4.964 terhadap produktivitas kerja dengan nilai signifikan sebesar $0,000<0,05$. Artinya pentingnya pemahaman dalam penggunaan teknologi informasi dapat ditingkatkan agar mencapai hasil yang optimal dan karyawan terbiasa dengan penggunaan teknologi dimana saja tanpa harus ke kantor dengan memberikan fasilitas sesuai kebutuhan karyawan.

4. Secara Simultan atau bersama-sama variabel time, room dan peran sosial berpengaruh terhadap produktivitas kerja BJTI Surabaya sebesar 52.230 dengan signifikan $0.000<0.05$.

5. Dari variabel time, room dan peran sosial nilai beta yang tertinggi adalah variabel time sebesar 0.521. Dengan demikian waktu yang berpengaruh dominan terhadap produktivitas karyawan BJTI Surabaya. Artinya semakin tinggi kemauan dan komitmen karyawan dalam menggunakan waktu dengan baik apalagi terhadap pekerjaan kantor dan keluarga, maka produktivitas kerja karyawan juga semakin meningkat dengan membuat jadwal harian atau schedule supaya tetap produktif.

\section{Saran}

Berdasarkan hasil penelitian yang telah dilakukan, penulis dapat memberikan saran sebagai bahan pertimbangan bagi beberapa pihak. Adapun saran sebagi berikut:

a. Hendaknya pemimpin memperhatikan karyawan yang masih terkendala dengan fasilitas kerja dan jaringan internet pada saat masa Work from home dan memotivasi karyawannya agar tetap disiplin dalam manajemen waktu dengan sebaik-baiknya. Dengan memberikan fasilitas kerja dan kuota yang dapat mendukung pekerjaan karyawan sesuai latar pekerjaan masing-masing.

b. Hendaknya pimpinan menyarankan selalu berkoordinasi sesuai dengan tim yang sudah dibuat dengan memotivasi dan memberikan pelatihan dan reward terhadap karyawan yang dapat bekerja dengan tim dan mencapai target ketika Work from home.

c. Hendaknya karyawan juga tetap giat dan semangat dalam menjalankan tugas-tugas pada masa Work from home serta menjalankan peran dan tanggung jawabnya di keluarganya tanpa merasa terbebani apalagi ketika menemani anaknya yang masih sekolah daring dan memberikan reward bagi karyawan yang menyelesaikan tugasnya tepat waktu.

d. Peneliti selanjutnya menyarankan hendaknya memakai variabel lain yang dapat mempengaruhi produktivitas kerja karyawan. Serta metode yang digunakan untuk menganalisa penelitian yang diteliti. 
INOBIS: Jurnal Inovasi Bisnis dan Manajemen Indonesia

Volume 04, Nomor 03, Juni 2021

Julika Pasaribu, Mochammad Isa Anshori.

\section{Daftar Pustaka}

Afandi, M. (2016) Human Resources Management, (1 ${ }^{\text {th }}$ Edition), Group Penerbit: CV. BudiUtomo.

Awan, A. G. (2015). "Impact Of Working Environment On Employee's Productivity: A Case Study Of Banks And Insurance Companies In Pakistan”. European Journal of Business and Management, Vol. 7: 329-341.

Baker, Azmi., (2017). "Satisfaction and Perceived Productivity when Professionals Work from Home". Research and Practice in Human Resource Management, Vol. 15: 37-62.

Bloom, N., Liang, J., Roberts, J., \& Ying, Z. J. (2015). Does working from home work? Evidence from a Chinese experiment. Quarterly Journal of Economics. Diakses dari https://doi.org/10.1093/qje/qju032. pada tanggal 20 September 2020.

Ernawati (2017). "Pengaruh Disiplin Kerja Terhadap Produktivitas Kerja Karyawan Non Medis Di Rumah Sakit Islam Siti Aisyah Madiun”. Laporan Peneltian Madiun: Sekolah Tinggi Ilmu Kesehatan .

Gądecki, J., Jewdokimow, M., \& Żadkowska, M. (2018). “New technologies and family life in the context of work at home. The strategies of work-life balance”. Studi Humanistyczne $A G H$. https://doi.org/10.7494/human.2018. Diakses pada tanggal 23 September 2020

Garg, V. (2015). "The Benefits And Pitfalls Of Employees Working from Home: Study Of A Private Company In South Africa". International Journal of Corporate Board: Role, Duties \& Composition, Vol. 11: 36-49.

Ghozali, Imam. (2011). Aplikasi Analisi Multivariate Dengan Program IBM SPSS, Edisi ke 7, Badan Penerbit Universitas Diponegoro

Hasibuan, M. (2014). Manajemen Sumber Daya Manusia, Cetakan ke Lima, Jakarta, PT. Bumi Aksara.

Hasibuan, M. (2017). Manajemen Sumber Daya Manusia, Cetakan ke Lima, Jakarta, PT. Bumi Aksara.

Helena, M. (2020). "Pengaruh work from home terhadap Work-life balance pekerja perempuan di kota Ende". Jurnal Ekonomi , Vol. 7: 2047-258.

Herijanto, N. (2019). Pengaruh Disiplin Kerja Terhadap Produktivitas Karyawan di PG. Krebet Baru Malang . Jurnal Administrasi dan Bisnis, Vol. 13: 57-64.

Kri, K. (2010). "Pengaruh Disiplin Kerja Terhadap Peningkatan Produktivitas Kerja Karyawan Di Pt. Muara Sejati Pekanbaru”. Laporan Penelitian Riau: Universitas Islam Negeri Sultan Syarif Kasim.

Manullang, Peniel. (2012). "Lingkungan Kerja Terhadap Semangat Kerja Dampaknya Terhadap Produktivitas Kerja Karyawan Pada PT. Telekomunikasi Tbk Bandung." Human Resource Area-oo. Laporan Penelitian Bandung: Universitas Komputer Indonesia.

Mungkasa, D. (2020). "Bekerja dari Rumah (Working from Home/WFH): Menuju Tatanan Baru Era Pandemi COVID 19". The Indonesian Journal of Development Planning , Vol. 4: 126-148. 
Mustajab, A. (2020). "Fenomena Bekerja dari Rumah sebagai Upaya Mencegah Serangan COVID-19 dan Dampaknya terhadap Produktifitas Kerja". The International Journal Of Applied Business Tijab University of Yapis Papua, Indonesia, Vol. 4: 13-21.

Pramuji, R. (2017). “Analisis Pengaruh Lingkungan Kerja Terhadap Kinerja Karyawan Pada Dinas Kepemudaan Dan Olahraga Kabupaten Indramayu".Laporan Penelitian Yogyakarta: Fakultas Ilmu Keolahragaan Universitas Negeri Yogyakarta.

Pravinah M, D. (2020). "He Psychological Impact Of Working from Home During Coronavirus (Covid 19) Pandemic: A Case Study. Cnr's”. International Journal of Social \& Scientific Research, India, Vol. 6: 18-27.

Purwanto, F., \& Mufid, A. P. (2020). "Impact of Work From Home (WFH) on Indonesian Teachers Performance During the Covid-19 Pandemic : An Exploratory Study". International Journal of Advanced Science and Technology Vol. 29, No. 5, Vol. 29: $6235-6244$.

Putnik, K., Houkes, I., Jansen, N., Nijhuis, F., \& Kant, Ij. (2018). "Work-home interface in a cross-cultural context: a framework for future research and practice". International Journal of Human Resource Management, 5192(January), 1-18. https://doi.org/10.1080/09585192.2017.1423096

Rizkiyani, N. (2013). "Pengaruh Relationship Marketing Terhadap Loyalitas Nasabah Dengan Kepuasan Sebagai Variabel Intervening (Studi Kasus Pada Bri Kantor Unit Pageruyung, Kendal)”. Laporan penelitian Semarang: Universitas Negeri Semarang.

Rupietta, K., \& Beckmann, M. (2016). "Working from home: What is the effect on employees' effort?”. WWZ Working Paper, University of Basel, Center No. 07, 5-20.

Sanjaya, Wina. 2015. Penelitian Pendidikan Jenis, Metode dan Prosedur. Jakarta: Prenamedia Group.

Sanyoto, Danang. 2012 Manajemen Sumber Daya Manusia. Yogyakarta: Caps

Sari, I. (2019). "Pengaruh Penerapan Jam Kerja Fleksibel Pada Dosen Di Lingkungan Ptkin (Studi Pada Dosen Iain Surakarta)". Laporan Penelitian Surakarta: Universitas Islam Negeri Surakarta.

Sarwono, Jonathan (2011). Analisis Data Menggunakan SPSS, Yogyakarta : CV.Andi Offset.

Shahid, S. (2020). Work from home during COVID-19: Employees perception and experiences. Journal of Organizational Change Management, Volume 9 ISSUE-5, MAY, 9, 51-53.

Sheikh, M. A., Ashiq, A., Mehar, M. R., \& Hasan, A. (2018). "Impact of Work and Home Demands on Work Life Balance: Mediating Role of Pyrex Journal of Business and Finance Management Research Impact of Work and Home Demands on Work Life Balance : Mediating Role of Work Family Conflicts. Pyrex" Journal of Business and Finance Management Research, 4(5), 1-10.

Shimawua, C. E. (2017). “The Effect Of Work Environment On Employee Productivity: A Case Study Of Edo City Transport Services Benin City, Edo State Nigeria”. European Journal of Business and Innovation Research, Vol.5: 23-39.

Simarmata, R. (2020). "Pengaruh work from home Terhadap Produktivitas Dosen Politeknik Negeri Ambon". Jurnal Ekonomi, Vol. 2: 72-82. 
Sugiyono, 2012, Metode Penelitian Kuantitatif dan Kualitatif dan R\&D, Bandung, CV. Alfabet.

Susanto, O. (2011). "Pengaruh Motivasi Terhadap Produktivitas Karyawan (Studi Kasus PT. BPR Bhakti Daya Ekonomi Yogyakarta". Laporan Penelitian Yogyakarta: Fakultas Ekonomi Universitas Sanata Dharma.

Sutrisno, (2011). Manajemen Sumber Daya Manusia, Cv. Kencana.

Tulenan,S.(2015).'Pengaruh Disiplin Kerja Terhadap Produktivitas Kerja Karyawan Pada Hotel Travello Manado”. Laporan Skripsi Manado: Politeknik Negeri Manado .

Yuwono, dan Mudjia, Raharjo. (2011), Metode Penelitian Kuantitatif. Jakarta, PT. Rajagrafindo Persada. 